\title{
Philippe Ariès e a história no tempo:
}

O registro francês de um historiador outsider

\footnotetext{
Como citar este artigo: MOTA, Manoel Santos. "Philippe Ariès e a história no tempo: O registro francês de um historiador outsider", Intelligere, Revista de História Intelectual, no7, p. 161-194. 2019. Disponível em $<$ http://revistas.usp.br/revistaintelligere $>$. Acesso em dd/mm/aaaa.
}

Resumo: O estudo investiga a biografia e o percurso profissional de Philippe Ariès [1914-1984], historiador francês pouco divulgado no cenário brasileiro, que é considerado um precursor da História das Mentalidades e um expoente da renovação da Escrita da História no século XX. O artigo enseja, nestes traços, desvelar a formação do historiador, fazendo conhecer a sua cultura política e histórica, esferas estas que foram seminais no executar de seu posterior ofício historiográfico. Para tanto, promove-se, em continuidade, uma exegese de sua obra intitulada Le Temps de l'Histoire, livro mister em que Ariès expôs e refletiu sobre suas visões da História da História, Teoria e Metodologia da História e História da Historiografia.

Palavras-chave: Teoria da História; História da História; História da Historiografia; Escrita da História; História da Cultura; Cultura Histórica

\footnotetext{
${ }^{1}$ Historiador, Universidade do Estado da Bahia. Estuda Teoria e Metodologia da História, com interesse particular nas dimensões do saber historiográfico ligadas à História da Cultura, História Intelectual, Imagem-História, História da Sexualidade. Professor da Rede Pública e Privada, na Educação Básica e Superior, do Estado do Bahia. Email: mannoell.motta@gmail.com
} 
Philippe Ariès and the history on the time: the French inventory of the outsider historian

Abstract: The article discusses the Philippe Ariès's [1914-1984] biography and professional path. He witch was a relevant French historian, considered a pionner in History of Mentalities and an exponent of the renewal of the Writing of History in the $20^{\text {th }}$ century. However that, he is unfortunately little publicized in the Brazilian scenario. Thereby, this study wishes to unveil the formation of the historian and his political and historical culture, seminal spheres in his historiographic career. Thenceforth, this article makes an exegesis of the study Le Temps de l'Histoire, a book in which Ariès did substantial reflections on History of History, Theory and Methodology of History and History of Historiography.

Keywords: Theory of History; History of History; History of Historiography; Writing of History; History of Culture; Historical Culture

\section{Primeiras palavras}

Os expoentes do pensamento historiográfico da Cultura Ocidental são muitos. Diversas e conflitantes são, assim, também, as postulações metodológicas e objetos epistêmicos a que deram vida.

De sorte somente a ilustrar as proporções deste embaraço, pode-se aventar aqui, sintomaticamente, as diferenças seminais que distanciaram - ou são usados para isto - a Escrita da História empreendida na França daquela realizada na Inglaterra: ambos os contextos intelectuais se ocuparam, na segunda metade do século XX, de dar voz aos sujeitos alijados das malhas do Estado e do poder.

O objetivo fundante era, pois, evocar e ecoar os marginais, os de baixo, em suas condições de existência. Isto é, queria-se elucidar seus modos de organizaçãa e manutenção da vida. Reunidos, tais norteamentos ganharam proeminência e foram apreciados sob a rubrica História Social - ou History from bellow, conforme preferiam os britânicos.

Paradoxalmente, não obstante as finalidades análogas, a escrita histórica feita no primeiro e no segundo país elegeu, como se sabe, escopo 
muito diverso e até mesmo colidente quanto a seus Objetos, Métodos, Fontes e Hermenêutica. ${ }^{2}$

A rigor, se tomado somente o contexto historiográfico francês, que é o espaço de maior atenção deste estudo, vê-se que em nada se atenuou as mencionadas tensões conceituais ou mesmo a heterogeneidade intelectual. Antes, pelo contrário, a virada do XIX para o XX, e o primeiro quartel do último século, assistiu grandes reviravoltas não apenas na História, mas também na Sociologia e Antropologia, levadas a cabo pelo pequeno país do oeste europeu.

Foi assim que, neste contexto, houve a afirmação da Sociologia e da História frente às demais Ciências do Homem, donde resultou intensa busca por valoração individual, bem como a ferrenha competição entre as duas áreas: em que se buscou aferir qual campo ofertava melhor e mais apurada lente de compreensão da sociedade. Todo este cenário é esmiuçado em trabalho clássico de Fernand Braudel (1965).

Notadamente no campo da História, a passagem da Evénémentielle para a Nouvelle Histoire acendeu e acentuou calorosos embates sobre as especificidades, utilidades e objetivos do trabalho historiográfico. Tributária desta discussão, a École des Annales consagrou o lugar em que se investigou os modos de produção e reflexão da operação historiográfica e sobre o métier da história no século XX. Neste corolário de produção teórica e metodológica, diversos nomes ganharam expressão e notoriedade. Lucien Febvre, Marc Bloch e Fernand Braudel, seguidos de Ernest Labrousse, Pierre Chaunu, Robert Mandrou, Jacques Le Goff, Emmanuel Le Roy Ladurie, Marc Ferro, Pierre Nora, Roger Chartier, Jacques Revel e André Burguière são-nos bastante conhecidos, posto que todo mínimo bom exame do tema, invariavelmente, os vai listar (Estado de São Paulo, 16.05.2014). Conquanto, no letreiro dos

\footnotetext{
${ }^{2}$ Não constitui objetivo aqui esmiuçar a dualidade História Social Francesa versus História Social Britânica ou ainda as clivagens entre a Escola dos Annales e a Escola Marxista Inglesa, não porque configurem temas desinteressantes, mas, por que, o caminho, desta vez, é outro. Assim, a consulta dos dois próximos textos certamente valerá a pena, pois oferecem panorama ilustrativo sobre o assunto. Trata-se de Peter Burke (1991) e Gutmaro Gómez Bravo (2003).
} 
expoentes historiadores do XX, um nome quase sempre recebe pouca luz, qual seja, o de Philippe Ariès.

Mormente mencionado somente quando se examina a Terceira Geração dos Annales, em torno de elucidação de sua dilatação temática, que abarcou, como se sabe, da Sexualidade aos costumes ante a Morte; Ariès não raro é apresentado como nota de pé de página a jovens pesquisadores, de maneira especial em vista de menção à História das Mentalidades e seus temas de costume, quais sejam, a Vida Privada, a Morte, e a Criança, cujos alinhavamentos se processam no terreno inefável, e por isso sob suspeição, da Subjetividade. O que é uma enorme lástima!

Toda esta conjuntura de marginalidade do historiador é aclarada por múltiplas vias. Sendo, até o presente, difícil precisar qual seja a melhor ou mais fidedigna explicação; mesmo considerando importantes acervos de fontes, a saber os Arquivos Philippe Ariès e suas Autobiografias. ${ }^{3}$

\section{Philippe Ariès, Vida e Obra}

Philippe Ariès (1914-1984) nasceu em Blois, França, oriundo de família burguesa, reacionária, monarquista e antirrevolucionária. De família nuclear, contou que sua casa era abundada além de seus pais - Emile e Yvonne Ariès, engenheiro e dona de casa, respectivamente -, de outras muitas parentelas: tios, primos, avós e muitos empregados. Sua infância foi, deste modo, recheada de experiências de familiares, donde brotaram muitos "causos" de tempos passados: episódios da monarquia francesa e eventos históricos e políticos que figuraram em seu imaginário infanto-juvenil por muito tempo.

\footnotetext{
${ }^{3}$ Destes arquivos resultaram importantes trabalhos, cuja expressiva maioria ainda não tem tradução do francês. Listo em seguida os mais robustos: Philippe Ariès (1993; 1994; 2013), O livro de 1993 trata-se de publicação póstuma e acrescida de analítica de Roger Chartier, feita a partir do espólio do historiador; e Guillaume Gros (2006; 2008; 2011; 2013). Há, por fim, site eletrônico dedicado à vida e obra de Philippe Ariès criado por iniciativa do historiador Guillaume Gros, pesquisador do centro de estudos Francia, Amériques e Espagne: societés pouvoirs acteurs - FRAMESPA - da Université de Toulouse-Jean Jaurès. Disponível somente em francês: $<\underline{\text { http://philippe-aries.histoweb.net/>. }}$.
} 
A este respeito, as descrições do historiador sobre as conversas que tivera e ouvira dos avós, familiares e empregados - oriundos da Martinica e de quem descreve muitos hábitos lingüísticos e de vestuário - nas tardes de férias e feriados, na casa do avô, em Bourdeaux, compõem um cenário particular, que merece ser vislumbrado sobre Memória e História (Ariès, 1994). Apaixonado por livros de história - notadamente os tradicionais -, seu avô vivia às voltas com eles. Além deste, seu reacionário professor do liceu teve importância em seu encanto pela história na juventude. Deste modo, o contexto familiar e educativo fez brotar no pequeno Ariès um confesso sentimento de intimidade e interesse pelo passado, as portas de acesso a ele, assim como as formas de sua narração.

Estudante difícil e intransigente, cuja formação básica se deu nos liceus Janson de Sailly e Saint-Louis-de-Gonzague - de orientação jesuítica -, ambos situados nos arredores de Paris, por vontade paterna foi cursar graduação em Engenharia. Embora não fosse seu interesse primeiro, achou que podia fazê-lo com gosto, posto que era afeito a cálculos. Todavia, não tardaria a desanimar da tarefa: a quantidade de dados que devia memorizar, a forte competição evidenciada no curso, assim como a rigidez do ritmo de estudos o desmotivariam rapidamente. Com assiduidade rara à graduação, seu pai logo foi convencido a permitir que jovem estudasse História; mas que fosse distante de Paris (Ariès, 1994, Campos, 2012).

Ocorre que o jovem havia se engajado em movimentos políticos de centro-direita, que preocupavam a família. Participou movimento reacionário de Charles Maurras, primeiro com os secundaristas e universitários da Action Française, depois colaborando com o Étudiant français, entre 1936 e 1939, onde redigiu cerca de vinte artigos políticos. Envolveu-se também em manifestações de rua e ciclos de palestras de formação política conservadora. Por fim, durante a Segunda Guerra Mundial, participou de ações da Revolução Nacional e ensinou em Centros de Juventude. Na liberação, ele colaborou durante alguns meses no Semanário do Partido Republicano da Liberdade (PRL) de André Mutter. Seu último engajamento político direitista, entre 1955 e 1966, foi Semanário Monarquista, La Nation française (Gros, 2011; 2013). 
Não demorou até que o jovem conseguisse transferência da graduação já em História na Université de Grenoble para a capital, adentrando, assim, à Sorbonne. Ariès confessou ter vivido em meio a muitos conflitos existenciais e que sofreu muito com eles: conflitos de ordem acadêmica e de cunho ideológico-político. Em seu contexto de formação, as perspectivas historiográficas e seus mestres eram demasiado tradicionais e desligados de sentido real. Reportando-se a sua fase de calouro em Grenoble, Ariès disse ter chegado deslumbrado, como um neófito, com os conhecimentos do passado a que teria acesso. Contudo, para sua tristeza, viu nos já velhos de ofício, os veteranos, uma desilusão que o assuntou. Segundo contou, o curso reunia um punhado de trabalhadores sérios, que aspirava tão somente o magistério, superior e escolar, sem maiores lucros - menção à produção de trabalho histórico inédito, talvez. Tratava-se, desta feita, em suma, segundo termos seus, de um "público pequeno, modesto, um pouco medíocre e sem imaginação", que deveras o alarmou (Ariès, 2013, p. 269-275).

Também a esta altura, já tivera contato com movimentos estudantis e grupos de reflexão políticas, em que vivera conflitos quando a sua formação direitista. Eles já não se encaixavam tão bem em sua nova inteligibilidade ou mesmo na conjuntura e conflito da Modernidade conturbada de fins do primeiro quartel do XX, com os abalos epistêmicos que propôs, a saber: descrédito do Estruturalismo, críticas à ordem político-econômica capitalista e ao conservadorismo na cultura e no comportamento. Matérias estas a que não poderemos, mais uma vez, nos deter aqui.

Ariès revelou, ainda, que somente apaziguou-se consigo após sua maturidade. Quando descobriu objetos heurísticos com os quais pode empreender um trabalho intelectual em que, de fato, enxergava relevância, epistêmica e social, e quando esquematizou em si a diversidade hermenêutica a que foi exposto e de que foi produto; na família, na Academia, e posteriormente, no seio profissional. Noutros termos, apenas quando engendrou um labirinto em que organizou, canalizou e sintetizou as múltiplas referências em que foi formado é que pode sentir-se seguro de seu estatuto como exegeta e hermenenta, enfim, como bistoriador. 
Finalizado os estudos, Ariès decidiu-se pelo magistério e então vislumbrou a Sorbonne, que já era um prestigiado centro mundial na pesquisa universitária em Ciências Sociais. Note-se, ademais, que concurso docente para esta instituição era uma enorme raridade, pois só ocorria em caso de morte ou aposentadoria de um catedrático, o que ocorria, esta última, somente por volta dos setenta anos. Surgiu, pois, a vaga e Ariès prestou agrégacion - modelo europeu rígido e complexo de concurso para docência universitária -, duas vezes, sendo reprovado na fase final, a oral, em ambas. Em verdade, na segunda tentativa, ele foi classificado em segundo lugar, mas, sem nenhuma vaga, no concurso de 1941 (Chartier, 2013; Novaes, 2016; Prost, 2008).

Tais experiências marcaram profunda e negativamente o historiador. Afinal, a esta altura seu arcabouço e experiência historiográfica eram já notórios. Não obstante a isto, não se deu à empreitada de modo presunçoso. Antes, sua preparação para o concurso previu rotina intensa. Nos duros anos da Segunda Guerra, de 1939 a 1941, Ariès passava os dias estudando na Bibliothèque Nationale de France, das 09 h00 às $18 \mathrm{~h} 00$, e de lá só saía por que ao cair da noite um funcionário anunciava, em alarido, que iam fechar, e sem muitas maneiras punha para fora do prédio todos os presentes. Nestes anos, contou o historiador que tomou contato profundo com o melhor da historiografia da época e os pioneiros dos Annales (Ariès, 1994).

Não se dispõe de clarezas quanto ao motivo das reprovações. Quais teriam sido as falhas orais ou procedimentais do historiador, posto que houvesse sido aprovado na fase escrita? Sua autobiografia apenas informa do amargor da derrota e de que somente compreendia sua reprovação pelo fato de não pertencer à acirrada intelligentsia universitário-historiográfica francesa da primeira metade do século XX (Ariès, 1994). Sem maiores minúcias, infelizmente.

Ainda sobre a marginalidade acadêmica de Ariès, vejamos alguns apontamentos sobre a École des Annales e as disputas de notoriedade em seu interior. Consta que no acender do XX o meio acadêmico parisiense constituía verdadeira miragem de intelectuais de distintas áreas, dos quais muitos estavam já em avançada idade. A respeito da concorrência no contexto intelectual 
europeu, Pierre Bourdieu (1983) informou em texto clássico que as queixas e o desgosto com os ares interioranos das instituições fora da capital compunham a ordem do dia. O próprio Ariès confessou que para sua "faculdade de província - Grenoble - nenhum professor brilhante conseguia atrair bom público para a História". Ainda segundo o historiador, a exceção ao contexto interiorano deu-se com o filósofo Jacques Chevalier, intelectual prestigiado, era um sucesso de público nos auditórios de Grenoble (Ariès, 2013, p. 269ss).

Paris era, assim, tão desejada que por duas vezes opôs os parceiros Lucien Febvre e Marc Bloch em disputa ácida por candidatura universitária. A correspondência trocada entre Bloch e Febvre por cerca de quinze anos [19281943] e examinada pelo suíço Bertrand Müller (1994), em coleção de três tomos, revelou que rixas entre os annalistes constituiu, de fato, uma realidade; que foi, por força deles mesmos, o mais das vezes escamoteada. Via de regra, publicizar as disputas internas do grupo não era, para eles, estratégia inteligente na luta por mercado editorial e notoriedade acadêmica. Note-se também que, segundo contou Müller, em seus primeiros anos os Annales viveram enorme instabilidade: faltava dinheiro, assinantes e autores, e os que chegavam tinham pouca destreza e má redação. Estas, entre outras questões, desassossegavam os precursores e avolumaram a correspondência de desabafo (Müller, 1994).

Desta sorte, na carta datada de 31 de Outubro de 1930, no contexto de candidatura junto à École de Hautes Etudes en Sciences Sociales, em tom duro, Febvre disse que a "escrita não era capaz de externar seu aborrecimento, pois não se podia usar meias palavras ante crise daquela proporção [...]”. E continuava: "em virtude de quem eram e o que representavam, mereciam, ambos, chegar à Paris. Contudo, para a boa realização de tal projeto, não podiam sequer dar a impressão de que fossem competidores" (Müller, 1994, XLVIII).

Por fim, ao cabo de algumas tentativas, os dois, de fato, galgaram posição no seleto círculo historiográfico parisiense, o seu grande projeto profissional: Lucien Febvre foi admitido no Collège de France, em 1932, e Marc Bloch à Sorbonne, em 1936 (Neves, 2012). 
Por seu turno, Hervé Coutau-Bégarie (1983), que estudou a École des Annales, mas sem dela fazer parte, também engrossou as acusações contra os annalistes. Para fundamentar sua visão sobre um suposto contexto de "conluio" da comunidade, Coutau-Bégarie utilizou especificamente o exemplo de Philippe Ariès em contraste com Fernand Braudel. De acordo ele, mesmo tendo publicado primeiro que Braudel, Ariès foi absolutamente preterido e deixado às sombras pelo fato de não pertencer ao grupo de annalistes, que, por sua vez, fez muito barulho e rendeu loureiros à posterior obra de Braudel, que já nascera um clássico, mesmo um ano depois (Coutau-Bégarie, 1983).

A malícia de Coutau-Bégarie se reporta à publicação dos clássicos Histoire des populations françaises et de leurs attitudes devant la vie depuis le XVIII siècle (1948), de Ariès, e La Méditerranée et le Monde Méditerranéen à l'Époque de Philippe II (1949), escrita por Fernand Braudel, que, em seu entendimento, comprovam as muitas querelas no interior da produção histórica francesa do XX. Em suma, o tratamento diferenciado reservado a Ariès e Braudel evidencia, segundo Bégarie, que a notoriedade intelectual não se dava naquele contexto somente por mérito e obras pioneiras; mas, sim, fundamentalmente, por quem grassava bem quisto na comunidade historiográfica (Coutau-Bégarie, 1983).

Em que pese as ácidas observações pouco crentes na amistosa convivência da diversidade no renovar da historiografia europeia, é equivocado, contudo, acreditar que Ariès rivalizasse com os expoentes do Annales - o que não garante que o contrário não ocorresse -, pois ele destacou, abundantemente, a contribuição dos primeiros annalistes na execução de sua empiria (Ariès, 1994; 2013).

Há mesmo quem diga que não houve animosidades e que Ariès não se melindrou ante o descrédito intelectual com que foi tratado, convivendo sem sobressaltos com os acadêmicos de seu contexto (Novaes, 2016). Mas, há, de outra banda, também controvérsias sobre isto. Constitui fato que sua narrativa destes episódios esboçou, em leitura atenta, ao menos, certo amargor. Fato também vislumbrado em Georges Duby (1989; 1993; 2015), que trabalhou com objetos históricos e metodologias próximas às de Ariès, e que, mais tarde, dirigiu em sua companhia a prestigiada Coleção Historie de la Vie 
Privée [1986], na Editions du Senil. Nas autoanálises que fez de sua trajetória intelectual e acadêmica, Duby também se ressentiu da concorrência acirrada no interior dos Annales.

Retomando o rumo, a aprovação na primeira etapa do concurso na Sorbonne rendeu a Ariès o convite para trabalhar no interior francês, o liceu de Rennes, com a modalidade do ensino médio. Ao que ele recusou. Mais tarde, porém, acabou lecionando nesta modalidade, mas por pouco tempo, pois tivera muitos conflitos com o diretor da instituição, cujas causas, são desconhecidas.

Já a meia idade, sem oportunidades na carreira universitária e tendo sido frustrado em suas experiências no magistério, Ariès foi trabalhar na burocracia do governo francês. Em 1943, assumiu o cargo de Diretor de Documentação no Institut des Fruits et Agrumes Coloniaux [IFAC $]^{4}$ [Instituto de Frutas e demais Cítricos Tropical-Coloniais], ligado à pasta da Agricultura do governo. Em que pese o posto pareça descabido para um cientista social, havia confluência com a formação Ariès, afinal, sua graduação acoplava História e Geografia, como era praxe na época. Daí que certo conhecimento sobre agricultura, mercado, condições climáticas, etc, faziam, sim, também, parte da expertise do historiador (Ariès, 1994).

Com efeito, Ariès ficou a frente deste cargo por quase quatro décadas [1943-1978], e com muita dedicação, segundo consta. Em verdade, conforme confidenciou em suas memórias, o trabalho no Instituto, por sua própria natureza, não lhe tomava o espírito, e, por fim, o expunha ainda à farta documentação de variadas frentes: culturais, econômicas, climáticas, de diferentes países. O que era uma vantagem (Campos, 2012).

Por sua vez, o trabalho historiográfico, restava, por assim dizer, para as horas extras a seu expediente de burocrata. Ariès era, como se autointitulava, um bistorien du dimanche [historiador de domingo]. A rigor, tudo leva a crer que

4 O IFAC foi criado durante a Segunda Guerra, em 1942, com objetivo de produzir conhecimentos, catalogação e estímulo à plantação de frutas e demais produtos tropicais nas colônias francesas do continente africano. Ariès cuidava da documentação e literatura relativos a frutas e demais produtos coloniais, bem como preparava publicações de auxílio aos investidores franceses nas colônias (Ariès, 1994). 
este título se refere mais a recurso de estilo do que à demarcação de um período de trabalho propriamente dito. Se escrevia à noite, nas horas de menor ritmo do expediente, ou se mesmo nos fins de semana, isto é, aux dimanche, [aos domingos] não sabemos bem. Por tudo isso, para quem não se dedicava full time à empiria, há que se dizer que Ariès construiu obra historiográfica memorável.

Seus grandes livros foram produzidos e publicados durante o período em que trabalhou no Instituto de Agricultura Tropical. Ariès era um aficionado pela leitura, pesquisa e escrita, e tinha como método a reclusão. Assim, escreveu a maior parte de seus trabalhos como anacoreta. Neste compasso, foram produzidos seus primeiros livros, Traditions sociales dans les pays de France (1943), Histoire des populations françaises et de leurs attitudes devant la vie depuis le XVIII siécle (1948) e Le Temps de l'Histoire (1954). ${ }^{5}$ A respeito destas primeiras publicações, consta que Ariès queria que seu segundo livro incluísse o termo vida e morte, mas foi impedido pelo editor - chamar-se-ia, assim, Histoire des populations françaises et de leurs attitudes devant la vie et la mort depuis le XVIII siécle. Por seu turno, como afirmado por Roger Chartier, em Le Temps de l'Histoire se encontra uma aguda analítica historiográfica e epistemológica, que nada deve a dos pioneiros da École (Chartier, 2013).

Em seguida houve as publicações de L'enfant et la Vie Familiale sous l'Ancien Regime [1960], livro que consagra o historiador ao ser traduzido para os EE.UU. Com tiragens editoriais imensas, virando best-seller nas Ciências Humanas e na Educação. $O$ que lhe rendeu inúmeros convites para conferências em universidades estadunidenses e também francesas, tais como a University Johns Hopkins e o Centre National de la Recherche Scientifique [CNRS], por convite de Henri Lefevre - quando este ainda era ligado ao Partido Comunista -, e em Aix-en-Provence Université, a convite de Pierre Guiral. Estas oportunidades encerraram cenários em que Ariès pode construir diálogos diretos com Michel Vovelle, Philippe Joutard e Paul Veyne, entre outros muitos.

\footnotetext{
${ }^{5}$ Mencionamos aqui os títulos e anos originais de publicações, sem considerar as traduções.
} 
O sucesso editorial estadunidense consagrou Ariès e chamou atenção do meio universitário também na França. O historiador e jornalista Michel Winock promoveu o relançamento de obras de Ariès na Seuil Editéur, dando início a uma série de entrevistas com o historiador. Carismático, bom orador, com fluência para conversação e sagacidade no relacionamento com as câmeras, Ariès amplificou o sucesso de sua obra, sendo assumido pelo público como exemplo de espírito não conformista (Gros, 2013).

As postulações do pensamento de historiador espraiaram-se, assim, pela França e redundaram em amizades produtivas. Os Arquivos Ariès trouxeram, pois, à tona correspondências que exprimem duas grandes fases na vida profissional do estudioso, uma de menor crédito junto à comunidade historiográfica e outra em que sua notoriedade restava, então, posta. ${ }^{6}$

No período anterior a 1970, uma primeira fase das sociabilidades de Ariès dava-se fora do terreno histórico, com literatos e membros ligados à Académie des Sciences Morales et Politiques, dentre os quais Daniel Halévy, Gabriel Marcel, Léon Bérard, Henri Boegner, Fustel de Coulanges, René Guillouin, Jérôme Carcopino, Jacques Chastenet, Adrien Dansette, e Jean Guitton (Gros, 2008; 2011; 2013).

A propósito da relevância destas amizades em seu percurso profissional, uma carta do historiador e demógrafo Louis Chevalier (19112001), encontrada no salão de Daniel Halévy, mostrou que as portas do Institut National d'Études Démographiques foram abertas para Philippe Ariès por seu intermédio direto. Registre-se que esta foi a única instituição a dar crédito aos trabalhos do historiador sobre Demografia e Contracepção, seus primeiros em que exercitou o campo que o consagraria mais tarde, as Mentalidades (Gros, 2008; 2011; 2013).

Por seu turno, ao largo dos anos 1970 sua correspondência passa a ser endereçada a Pierre Guiral, Maurice Agulhon, Paul Veyne, Michel Vovelle, Pierre Chaunu, Jean Delumeau, Jacques Le Goff, Emmanuel Le Roy Ladurie,

6 Para maiores desdobramentos destas correspondências deve-se conferir a produção de Guillaume Gros (2006; 2008; 2011; 2013). 
André Burguière, Georges Duby, e Pierre Vidal-Naquet. Cabe, ainda, registro especial para amizade muito próxima de Roger Chartier e Michel Foucault, com quem Ariès muito intercambiava reflexões teóricas e de quem publicou a tese doutoral, quando esteve à frente da editora Plon (Gros, 2013). Esta amizade ainda resultaria, em 1982, na organização de dossiê na Revista Persèe, juntamente com André Béjin, sobre as Sexualidades Ocidentais, tema caro a Foucault, como sabemos. Dois anos depois, em 1984, a publicação se tornaria livro coletivo dirigido por Ariès, Foucault e Béjin (Ariès; Béjin [Orgs.], 1982).

Com efeito, é oportuno, contudo, esclarecer que algumas cartas tratavam apenas de agradecimentos por envio de obras recentes, de um lado e de outro. Condição que não deixa de explicitar o novo panorama de relacionamentos do historiador.

Em 1978, já consolidado como historiador, o conjunto de sua obra somado ao vigoroso sucesso de público europeu e nas Américas finalmente legaram a Ariès convite para compor a Academia francesa. Tratava-se da Maison des Sciences de l'Homme, na École des Hautes Études en Sciences Sociales, um dos mais prestigiados centros mundiais de pesquisa em Ciências Humanas.

No fim da vida, rememorando seu percurso biográfico, Ariès se mostrou curioso de sua trajetória. Refletiu sobre a má vontade da comunidade historiográfica para consigo, nomeando os historiadores profissionais como "animais bizarros", ressentiu-se de seus fracassos e inquiriu o universo sobre as escolhas que poderia ter feito. Se tivesse aceitado o emprego de "segunda mão" que lhe fora ofertado por ocasião do segundo lugar na Sorbonne seria o mesmo intelectual que se tornara? Teria escrito os mesmo trabalhos? Estudado os mesmos objetos ou, quiçá, os jovens trariam-lhe outras curiosidades?. Ainda segundo ele, a única certeza é que, pelas promoções da carreira, em fins dos anos 1970 ocuparia, certamente, posto na Université Paris IV (Ariès, 1994, p. 136ss; 2013). Estes questionamentos atravessavam o pensamento de Ariès no início dos anos 1980 e expõem um homem curioso e inquieto consigo e com o mundo. 
Infelizmente, demorada que foi sua aclamação na universidade, Ariès pouco pode gozar de seu novo estatuto profissional, posto que morreria pouco depois, aos Oito de Fevereiro de 1984.

Após sua morte, seu material de trabalho foi agrupado em "uma dezena de caixas de papelão e organizados em função dos livros que escreveu" (Gross, 2008; 2013). Empreitada realizada pela esposa do historiador, Primerose Saint-Martin Ariès - artista plástica que muito contribuiu na indicação de fontes iconográficas relativas à Morte e à Infância para os primeiros trabalhos do marido.

Deste acervo restam inúmeras fichas de leitura, observações e reflexões sobre fontes - muitas redigidas à mão -, obras de arte e literatura, bem como enorme quantidade de rascunhos datilografados de obras já publicadas. Há também, em menor quantidade, rascunhos inéditos que foram tutelados à analítica do amigo íntimo Roger Chartier, que já reeditou algumas publicações, especialmente a coletânea autobiográfica Essais de Mémoire (Ariès, 1993).

Após a morte de Primerose Ariès, que ocorreu poucos depois da do historiador, este acervo documental e seus bens ficaram sob a guarda de MarieRose Ariès, irmã mais nova do pesquisador. Com o argumento de resguardar a intimidade da família, Marie Ariès dificultou o acesso ao acervo. Contudo, após muitas negociações, o material foi remetido ao arquivo da EHESS, encontrando-se disponível a estudos; arquivo do qual o já mencionado trabalho de Guillaume Gross muito se serviu.

Philippe Ariès, como vimos, se debruçou e investiu esforços sobre campos marginais e desacreditados, verdadeiramente relegados à espuma das realidades, quais sejam: a Vida privada, Infância, a Sexualidade, os Hábitos de Vida e Morte, a Cultura educacional, Normas ético-morais de convivência familiar e social, os Sentimentos e a Sexualidade. No que diz respeito ao caminho metodológico, de sorte a elucidar as questões heurísticas colocadas por estes objetos, ele indagou a Pintura, Literatura, Diários, Cartas, Monumentos Funerários, e variados outros Artefatos 
escritos. Fontes estas impensáveis, via de regra, ao bom ofício historiográfico de seu contexto (Estado de São Paulo, 16.05.2014; Marcos Silva, Mimeo).

Sua capacidade imaginativa avant-garde é outro dado extraordinário. Enquanto seus contemporâneos se ocupavam das correntes profundas da vida social, isto é, as estruturas, notadamente a Economia e a Política, Ariès se ocupou de temas que, para estes, flutuavam na superfície dos acontecimentos, sem, portanto, merecer crédito, e advogou que seus objetos constituíam campos seminais de análise social.

Segundo narrou, costumava andar pelas alamedas parisienses zeloso de conhecer os modos de construção dos hábitos, falares e dinâmica que via diante de si (Ariès, 1993). Assim, com empenho e engenhosidade, evidenciou que a Cultura, se tomada com rigorosidade metodológica e, claro, habilidade epistemológica, constitui elemento qualificativo ímpar de um tempo e povo, posto que expõe os porquês de a Vida e uma dada Mentalidade ser como está sendo - posto que já foi e será diferente, na conjuntura do tempo. Isto é, a Cultura demarca e exibe as entranhas sociais que transitam fora do domínio púbico e, em certo grau, da gerência do Estado.

Outro importante aspecto da trajetória de Ariès diz respeito a sua relação pessoal e passional com o conhecimento histórico. A ego-bistória produzida por ele - faz-se aqui menção clara ao análogo trabalho de Duby (2015) -, isto é, sua autobiografia, informou que o historiador foi atravessado pelo saber histórico de modo profundo e indelével, e dele não foi possível esquivar-se. Assim, no inventário que fez de sua jornada profissional, o historiador teve de examinar a vida pessoal - especialmente sua infância como via necessária de acesso a bem explicar as escolhas temáticas que fez, quando tomou a história por gosto e como ofício.

Distante das macroestruturas, longe dos eventos políticos e econômicos, foi tomado pelo interesse e pela dialética do passado nas conversas à mesa da família, nas historietas perpassadas pelos avós e nas crenças que estruturavam a tradição de sua família. Noutros termos, Ariès se 
formou a partir das mentalidades a que foi exposto e que passou a criticizar, após ter construído condições metódicas para isto.

Por seu turno, é verdade que os achados arièsanos sobre Cultura, Mentalidades, Infância, Sentimentos ante à Morte, Vida, à Família e ao Corpo encontram-se datados e melhor adaptados à certas estruturas materiais que outras. Assim, a respeito das críticas que recebeu por ter estudado grupos de elites e seus documentos bem como por encerrar comportamentos em temporalidades fixas, sem considerar a fluidez e mobilidade da cultura, Ariès respondeu com mea culpa. Assumiu que o empenho em desvelar suas temáticas fez com que muitas vezes sua argumentação o traísse e que, em verdade, nunca considerou que os objetos fossem estanques na história. Pelo contrário, em virtude da própria especificidade metodológica com a qual preferiu trabalhar, qual seja, uma história mais etnográfica, tinha mesmo que advogar pela fluidez, remodelações e resignificações entre as temporalidades e nunca o seu contrário.

No tangente aos grupos econômicos que examinou, argumentou que a abundância e a heterogeneidade de fontes consistiu um evento capital em suas escolhas. Afinal, a carência de registros por vezes dificultou, senão mesmo impediu, variadas intenções de estudos com a Cultura Popular.

A propósito dos estudos arièsanos com a Mentalidade as críticas foram abundantes, e mesmo de colegas próximos. Michel Vovelle, que também militou na mesma arena temática, por vezes acusou Ariès de ser "inventivo" no traçar de argumentações. Sua principal queixa advinha da pouca atenção do colega em quantificar os dados e fontes, tal como este fazia em seus trabalhos. De mesma sorte, outro "fogo amigo" partia sempre de Emmanuel Le Roy Ladurie - mesmo após a morte de Ariès. Em resenha ao Le Figaro, Ladurie qualificou Philippe Ariès como um "grande espírito, frequentemente equivocado e, por vezes, aloucado, mas, extraordinariamente engenhoso e sutil, com lampejos de genialidade" (Le Fígaro, 22.05.1997). Note-se que, mesmo nas críticas, a maior parte delas, encontra-se o inegável reconhecimento da engenhosidade do pensamento arièsano. 
Resta, certo, finalmente que as visões direitistas de Philippe Ariès encerraram enorme entrave a sua boa aceitação junto à engajada comunidade historiográfica da segunda metade do XX, especialmente a do contexto de 1970, que se viu obrigada a revigorar a "renovação". Movimento conhecido no debate historiográfico como Nova História, que foi engendrado e exprimiu os anseios de "novidades" da Terceira Geração dos Annales.

De sorte que o pós-1968 constituiu época que, como se sabe, encerrou demanda aguda por deslocamentos teóricos e inovações tanto na historiografia como na vida social; idealizadas, notadamente, a partir das ideias de Pós-Modernidade, nos movimentos de Contracultura e nos eventos das Revoluçoes cultural, sexual e revisão de ideologias politicas.

\section{Le Temps de 1'Histoire, 1954}

O livro O Tempo da História conjuga uma série de oito ensaios escritos por Philippe Ariès (1914-1984), ao longo dos anos 1946 a 1951. Posteriormente, os ensaios despertaram o interesse da University Johns Hopkins, respeitado centro universitário dos EE.UU., que convidou o historiador para uma série de conferências. ${ }^{7}$ Escritos separadamente, os textos foram depois compilados e distribuídos sequencialmente, mas, sem introdução ou conclusão na coletânea que aqui se apresenta.

O prefácio, nomeado $A$ amizade da História, contou com um extenso e detalhado ensaio de Roger Chartier - notório historiador e intelectual francês que realizou uma "escavação" bastante cuidadosa para apresentar o trabalho de historiador de Ariès, seu pensamento e trajetória intelectual.

Chartier iniciou sua reflexão apontando que $O$ Tempo da bistória é o livro menos conhecido de Philippe Áries. Esgotado das editoras desde há

\footnotetext{
7 Philippe Ariès preferiu trabalhar, contudo, com o tema que vinha lhe tomando os últimos anos de pesquisa. Tratava-se de seus estudos sobre a Morte, que a princípio haviam sido iniciados pela investigação dos cultos aos túmulos e aos cemitérios, e depois, ampliadas as fontes, resultaram na incorporação dos túmulos, da iconografia, da epigrafia funerária e dos testamentos assim como houve também visitas a igrejas, museus e cemitérios. Como se vê, embora tenha sido taxado negativamente de "intuitivo", Ariès analisou massiva documentação em suas pesquisas. Assim, o ciclo de quatro conferências ocorreu, por fim, em 1973 e deram origem ao livro conhecido como História da Morte no Ocidente. Sobre esta discussão, deve-se conferir Marcos Silva (Mimeo).
} 
muito - isso em 1980 quando Chartier escrevia sua introdução -, chegou a ficar quinze anos sem ser citado nas Revistas de História ou das Ciências Sociais, francesas ou estrangeiras, ou mesmo entre os estudiosos do Mundo Medieval e do Dezessete, temporalidades a que corresponderam longos ensaios da obra (Chartier, 2013, p. 07ss).

A exceção a este esquecimento foi o célebre historiador Fernand Braudel (1902-1985), no clássico História e Ciências Sociais: a longa duração, que utilizou $O$ Tempo da História em sua discussão sobre o distanciamento temporal entre historiador e seu objeto (Braudel, 1965, p. 275).

Publicado pela primeira vez em 1954, mas pouco utilizado mesmo entre os especialistas e admiradores do autor, como dissemos, O Tempo da História é "um livro esquecido!" (Chartier, 2013, p. 09). Realidade que, pelas lições que traz sobre Temporalidade histórica, Postura hermenêutica e Metodologia da bistória, urge ser revisada.

O livro detalha a cultura histórica do jovem estudante Philippe Ariès, formada a partir da conjugação da História Acadêmica, a Universitária e a Action de Française. ${ }^{8}$ Quanto à primeira, apresenta-se que foi feita por magistrados e homens das Letras, resguardando, assim, cunho essencialmente político, conservador. Quanto à segunda, empreendida por professores universitários, era hermética, doutoral, imparcial, e desligada dos leitores comuns. Em suma, era uma história de professores para outros professores, configuração esta de que muito se ressentiu o jovem e neófito - conforme termos do próprio Ariès estudante de graduação em história, ao se aperceber do tédio e desilusão que tomava seus veteranos (Ariès, 2013, p. 269-271).

Muito preocupada com a causalidade do fato histórico, a história universitária queria exumar, concatenar e explicar o passado. Por sua vez, a terceira influência na formação histórica de Ariès se refere ao trabalho Charles Maurras e de Jacques Bainville, escritores franceses ligados à Action Française, cuja escrita

\footnotetext{
${ }^{8}$ Um partido político de direita, com orientação contrarrevolucionário e monarquista, que cresceu no início do século XX. Seus membros provinham da pequena aristocracia de províncias francesas e seu maior ideólogo foi o historiador Charles Maurras. Para maiores esclarecimentos, deve-se conferir Philippe Ariès (1994) e Marcos Silva (Mimeo).
} 
histórica mantinha fortes tons da destituída monarquia conservadora (Chartier, 2013. p. 15ss).

A despeito de ter crescido em meio a esta historiografia em tudo conservadora, como se viu, a partir de uma "intuição" mais ou menos genuína somada a uma expressiva habilidade e gosto pela leitura, Philippe Ariès contou que aos poucos foi percebendo a existência de uma sociedade que não era explicada pela presença ou ausência do Estado. Isto o fez distanciar-se da história política e econômica - tônica da época - e voltar-se para a realização de uma história mais etnográfica, em estrita conexão com a Cultura, as Estruturas Mentais, e a Vida Privada (Ariès, 1994).

Assim, ele rompeu com seus mestres e decidiu não ter outros. Foi afirmando a cada nova pesquisa - temas escolhidos, o estatuto e o conjunto de fontes, etc. - uma inovadora forma de fazer a empiria histórica e a escrita da história.

Por seu turno, não obstante dirigisse uma coletânea na Revista da Editora Plon - editora de prestígio na época - entre 1946 e 1954, Philippe Ariès teve seus primeiros livros rejeitados para publicação pela editora. Noutros termos, Ariès se viu duplamente à margem do métier do historiador de seu tempo: tanto a academia quanto as editoras rejeitavam suas inovadoras leituras da História.

Em continuidade, seu primeiro livro, $A$ história das populações francesas e de suas atitudes diante da vida, obteve financiamento e foi, finalmente, publicado em 1948, ainda que por uma editora menor, a Edições Self.

Nesta perspectiva, a obra aqui analisada constitui também um belo panorama sobre os entraves ao trabalho intelectual do autor.

Em O Tempo da História os leitores assim encontrarão incursões às diversas maneiras de compreender, pesquisar e escrever a História: tradição familiar; universitária; historiadores da Action Française; Idade Antiga; Idade Média e Moderna; e a História Marxista (Chartier, 2013, p.10-16). 


\section{Le Temps de 1'Histoire, quadro a quadro}

No Capitulo i - uma criança descobre a história - há uma discussão dos contatos mais íntimos de Ariès com seu passado, através de uma retomada de sua experiência familiar com a história. Sua família era monarquista, saudosa do Antigo Regime e ligada à produção da Action Française. O historiador confidenciou, por exemplo, que todo ano sua mãe saía de Paris sob algum subterfúgio para não ter de assistir as comemorações da Revolução que derrubou a monarquia, que a escandalizavam (Ariès, 1994, p. 22).

Assim, "o sentimento da época de ouro [...], o passado feliz. e doce do Antigo Regime estava sempre presente na memória de seus parentes. De certa maneira, toda discussão política em sua casa terminava com uma referência ao tempo feliz dos reis de França [...]" (Ariès, 2013, p. 44ss, grifos meus, adaptado).

Todavia, as imagens que sua família fazia da Monarquia Francesa, vivas ainda em pleno século XX, 1925, passaram a incomodar Ariès em sua adolescência: eram demasiado infantis e ingênuas. Elas tinham ainda uma marca de gênero, qual seja, as narrativas mais pueris geralmente eram realizadas pelas mulheres. Por sua vez, os homens da família mesmo crentes na fidalguia dos tempos áureos, se preocupavam mais em seguir o ideal de classe da burguesia do séc. XIX, isto é, usufruir das vantagens econômicas do novo modelo político.

Conforme informou, suas memórias são importantes, pois explicam bem o modo como tomou contato com a ideia de tempo histórico: a partir da forte nostalgia do passado presente em sua vida privada. Desde muito cedo o historiador teve contato com o gênero histórico da crônica e das memórias que seus pais e outros entes familiares liam repetidamente. De sorte que, entretanto, este gênero passou a também incomodar o autor, que começou a notar repetições, saltos temporais, e ausências de continuidade e explicaçoes (Ariès, 2013, p. 46.). 
Assim, confessou o autor que embora as visões históricas memorialistas lhe causassem desconfiança foram fundamentais em sua escolha pela formação em História.

No Capitulo ii - A História Marxista e a História Conservadora - o historiador mostrou que o período entreguerras fez emergir um grande interesse pela história, que, dada a sua proporção, acabou por constituir um fato sociológico importante.

A história que se queria ler, no entanto, não era tal como a faziam os "doutos" da universidade, se buscava uma história legivel e compreensível ao leitor popular. Deste modo, do contexto pós-Primeira Guerra Mundial surgiu, nos termos de Áries, a vulgarização histórica, que acabou por se tornar uma verdadeira escola: tratava-se, pois de um gênero de escrita que fazia uma aproximação "bastarda" entre a História e o Romance, que viu explodir o número de leitores (Ariès, 2013, p. 58-61).

Os principais autores franceses deste gênero foram Jacques Bainville, Pierre Gaxotte e Théodore Lenôtre. Mas, o sucesso editorial foi tamanho que nem os acadêmicos ficaram de fora desta moda de escrever a história.

Aliada ao gosto por esta literatura histórica, a grande particularidade do séc. XX, contudo, foi, segundo Ariès, a certeza que os homens passaram a ter de que não eram seres absolutamente livres, autônomos. Neste contexto, a clareza de forças sociais externas a sua vontade descentraram o indivíduo do século XX. Dito de outro modo, o homem passou a ter consciência de si na história, donde surgiu seu interesse em compreender a mecânica desta relação de forças (Ariès, 2013, p. 62)

A este punhado de questões que homens e mulheres passaram a colocar, o Marxismo, ideologia do Dezenove, resurgiu como manancial explicativo que propunha uma interpretação da história a partir do movimento dialético das classes sociais e da evolução técnica. Áries advertiu, por fim, que embora Marx tenha sido do século XIX, considera que foi no século XX que o Marxismo tenha ganhado força e propulsão. As perturbações causadas nas 
sociedades burguesas após a Primeira Guerra Mundial, para ele, reinventaram o Marxismo enquanto modelo de pensamento (Ariès, 2013, p. 64).

As elaborações marxistas, segundo Ariès, se estruturavam no entendimento que Karl Marx tinha da história: pressupunha a existência de leis essenciais, que eram chaves de uma mecânica social que se repetiria rigorosamente durante o período de evolução.

Ainda segundo o historiador, o Marxismo perseguia o objetivo principal da derrubada das classes exploradoras do poder pelas classes exploradas, o que ocorreria em um estágio máximo das lutas, ligado ao desenvolvimento econômico-técnico do processo de Revolução (Ariès, 2013, p. 67).

Neste caminho, a bistória marxista mantinha uma profunda relação com ideia da repetição. Haveria assim a sequenciação de ciclos que se repetiriam segundo leis existentes, conceitos estes tomados à Economia para pensar a Humanidade. E é exatamente a contextualização teórica do marxismo que desagradava o historiador francês, que disse desconfiar da História tomada como uma finalidade total rumo ao progresso (Ariès, 2013, p. 70).

Para Ariès, assim, a "redução" da História feita pelo Marxismo ao jogo recíproco entre uma constante e uma variável era problemática: a constante sendo a coletividade humana, mecanizada, e por sua vez, a variável figurando como o estado econômico-técnico do mundo. Ainda segundo sua leitura, o Marxismo eliminava da História a diferença entre os Homens, pois concentrava fora da experiência bumana os fatores de variação e transformação, o que ele reprovava.

No entanto, não se deve tomar estas discordâncias como completa refutação do Materialismo Histórico por parte de Philippe Ariès. A intenção confessa do historiador era mais a de situá-lo na geografia das atitudes perante a História, por ele ali estudadas (Ariès, 2013, p. 68-70).

Por sua vez, no Capitulo iii - O engajamento do homem moderno na História - discute-se o quase desaparecimento da Vida Privada no séc. XIX. Segundo apontou o historiador, a dimensão política havia tomado a vida familiar, fazendo com que os problemas da esfera doméstica se vissem inundados por uma 
dimensão do político paralisante. Nesta situação Ariès viu uma invasão do Homem pela História (Ariès, 2013, p. 89-93).

Ainda segundo o historiador, foi também neste momento da vida moderna que a escrita transformou-se em testemunho. Isto é, construiu-se uma necessidade de comunicar sentimentos, vontades, desejos pessoais, que em algum momento encontrasse o devir coletivo; de modo a fazer falar a singularidade em sua representação de uma comunidade (Ariès, 2013, p. 93-105).

O historiador também explicou o que entendia por Testemunho. "É uma existência pessoal ligada intimamente às grandes correntes e a história coletiva. É também um momento da história apreendido em sua relação íntima com uma existência particular. Assim, o engajamento do homem na história é tal que não há mais autonomia, [...] mas o sentimento nítido de uma coincidência ou uma recusa entre seu destino e o devir de seu tempo" (Ariès, 2013, p. 111, grifos meus, adaptado).

O historiador ainda apontou que "testemunho não é relato indiferente de um observador que enumera ou de um cientista que desmonta, mas uma comunicação, um esforço apaixonado para transmitir aos outros que contribuem para a história a sua própria emoção da história". Testemunho, desta forma, não trata de "passar minhas ideias dogmáticas sobre a sociedade, o Estado ou Deus, mas minha maneira de ser e de sentir tal como ela se formou no interior de uma civilização" (Ariès, 2013, p. 112, grifos meus adaptado).

O Capitulo iv - Atitude diante da História na Idade Média - se inicia pela advertência de que a História nasceu, enquanto ciência, no século XIX, de modo que o que foi produzido anteriormente ficou conhecido na historiografia da época apenas como relato e não como fato histórico.

De acordo com Ariès, até a modernidade havia a compreensão da existência de uma vida com e outra sem história. Neste contexto, dizia-se sem história a vida dos povos da Antiguidade. Por sua vez, os povos com história seriam os povos dos períodos posteriores ao Cristianismo (Ariès, 2013, p. 123). 
Esta intelligentsia histórica promoveu imperiosa urgência de organizar a extensa, variada e emaranhada documentação dos períodos posteriores à expansão do Cristianismo pelo Ocidente a partir de temas e temporalidades lógicas. Trabalho colossal que acabou por dar vida à ideia de História Universal.

Neste ensaio, o historiador também comparou a História ao Mito. Segundo ele, a Mitologia estava nas sociedades antigas ou rurais para a explicaşão da vida assim como nas sociedades políticas e modernas estava a História. Isto é, em sua visão, por ter uma função muito parecida, a história seria o mito do Mundo Moderno (Ariès, 2013, p. 116).

De outro modo, conforme Ariès se se quer uma diferenciação entre estes sistemas de significação deve-se analisar o formato e o modo de operação de cada um: enquanto o Mito foi transmitido de geração a geração fundamentalmente pela oralidade e pela crença; a História, de sua parte, foi memorizada e lembrada, inclusive, pela escrita. De tal condição talvez tenha emergido o campo político como fundamento da história no mundo moderno. Afinal, dos faraós do Egito Antigo à formação dos Estados Nacionais no século XIX se pôde constatar a centralidade do discurso histórico político na cristalização de noções de verdade (Ariès, 2013, p. 117-20).

O Capitulo v - Atitude diante da bistória: o século XVII - apresentou o fato de até o século XVI o estudo da história ter privilegiado a Antiguidade Bíblica e a Antiguidade clássica e oriental. De modo que outros temas e temporalidades não foram concebidas como objetos de estudo. Isto é, segundo Ariès, a noção hoje consensual de continum temporal - sequenciação das épocas e o desenvolvimento de temáticas - não existia no século XVI (Ariès, 2013, p. 175ss).

Ato contínuo, do século XV até o XIX, a escrita da história na frança privilegiava um conjunto de temas, chamados gênero tradicional - quase de exclusividade política e religiosa -, que acumulava muitos leitores. Assim, edição após edição, por causa do apego do público, o tema variava pouco e quando modificado dizia respeito somente a algum embelezamento e cunho estilístico do autor, que forçava algum distanciamento dos colegas, mas sempre 
respeitando um modelo já pré-fixado. Desta sorte, a história era, pois, terreno para os continuadores.

Em que pese esta realidade, havia também entendimentos reticentes. No mesmo período, o Dezesseis, H. Hauser afirmava que se um acontecimento fosse bem escrito uma vez era inútil estudá-lo novamente (Ariès, 2013, p. 178). A despeito disto, em face da demanda do público, muitos temas - História dos Reinados e História da França, por exemplo - foram retomados para explicaşões complementares, nas quais apenas se retocava, em retórica e apêndices, as versões anteriores. Leia-se, então, retomados para continuação.

Assim, as histórias de continuação também seguiam o modelo fixado, afinal prevalecia a concep̧ção de história como narração de um fato. Isto é, pressupõe-se a inexistência de mudanças muito significativas. A este propósito, o lexicógrafo Antoine Furetière apontou em seu Dicionário Universal do francês de 1690 que a História era um "relato feito com arte: narração elevada, contínua e verdadeira dos fatos mais memoráveis e das ações mais célebres" (Ariès, 2013, p.180).

Um marco formidável nestas concepções de história foi a publicação do Tratado de História [Aviso sobre a História da Monarquia Francesa] por Charles Sorel, em 1628, no qual se criticava as narrativas fabulosas e os romances de cavalaria - traços da literatura histórica do contexto -, aconselhando mesmo a extinção do sobrenatural e do fantástico das narrativas históricas. Para Sorel, era importante que o historiador tivesse mais cuidado com a verossimilhança e a cronologia. Insights talvez do Cientificismo que viria a assolar a história científica do fim do Dezenove? (Ariès, 2013, p.182).

O Tratado configurou uma apurada lição de Metodologia da História ainda no século XVII. Além das preleções já apresentadas, o manual também recomendava que as recorrências aos textos antigos [latinos, gregos, romanos] não se dessem a partir da cópia, palavra por palavra. Segundo Soreal, devia haver uma inspiração neles, mas, a narrativa devia ser feita à maneira do historiador do tempo presente (Ariès, 2013, p.184).

No entanto, estas lições de metodologia não ficaram impunes. Muitas críticas foram feitas, pois já naquele contexto se acreditava que a citação literal 
das referências e das fontes era fundamental e valorizava o historiador. O principal crítico foi o Padre Daniel - estudioso da história do período - que, contudo, acabou por reconhecer que as minúcias dos documentos antigos muitas vezes mais haviam prejudicado que ajudado sua analítica.

Por fim, embora fosse uma preocupação latente desde o século XVI, atravessado o XVII e se firmado no XVIII, em seu tratado Sorel silenciou quanto às noções éticas e políticas que se devia extrair do conhecimento histórico. Sobre esta discussão, Antoine Furetière havia assinalado em seu trabalho que a história era um espaço onde se ensinava pela ação e pelo exemplo. Como se vê, desde estes longínquos tempos já se desenhava na história a sua função educativa e moralizadora, muito utilizada pelo mundo moderno para inculcar ideologias, como já experienciado (Ariès, 2013, p.186ss).

Pari passu, o ensaio prosseguia em demonstrar estes pormenores no estilo historiográfico dos escritores do período, em especial François-Eudes de Mézeray; Louis-Pierre Anquetil; Padre Jove; e Théodore Godefroy.

No Capitulo vi - História científica - Ariès apresentou os historiadores da primeira metade do século XIX e seu modelo de escrita histórica. Para ele, Augustin Thierry, François Guizot e Jules Michelet produziram uma história pouco elaborada, que ele nomeia de história romântica.

Ocorre que estes escritores se propunham a "evocar o passado em todos os seus aspectos pitorescos e saborosos. [...] Assim, nos seus relatos autênticos dos acontecimentos do passado, os historiadores buscavam o mesmo desenraizamento que orientavam os poetas e os romancistas" (Ariès, 2013, p.274ss).

Outro equívoco atribuído por Ariès a estes primeiros historiadores do mundo contemporâneo dizia respeito à ausência de método, que mais tarde foi adjetivado como cientifico. Deste modo, faltava a nossos precursores o cuidado do uso de fontes seguras, a análise e a escrita ocorriam também rápidas demais, mais ou menos nos moldes do romance histórico, conforme reiterou Ariès. 
Contudo, pouco a pouco foi sendo possibilitada a produção de uma história mais precisa na França da primeira metade do século XX, movimento que foi tributário do esforço de erudição - recolhimento e a compilação crítica de textos e documentos nos arquivos - de parte dos historiadores do período.

Por sua vez, Ariès também realizou neste ensaio uma diferenciação entre História Acadêmica e História Universitária. A primeira foi consumida pela burguesia conservadora e pelas elites católicas, isto é, burocratas aposentados e políticos (Ariès, 2013, p.280ss).

Escrita por inúmeros autores, "magistrados e gente rica que dispunha de tempo e dinheiro, pois viviam de rendas, e se deram a incursões leigas pela escrita da (e)história", a literatura bistórica acadêmica possuía um cunho altamente conservador e erudito e se propunha a narrar e explicar a evolução política do governo e dos estudos, as revoluções, mudanças políticas, agitações, crises e guerras (Ariès, 2013, p.279, grifos meus, adaptado). Em suma, era uma história que apregoava o determinismo bistórico conservador, que ignorava as reclamações da massa popular.

Por sua vez, a história universitária - seguindo a corrente - se dirigia mais aos leitores das universidades. Ela era hermética e significava mesmo uma história feita por intelectuais para ser consumida quase exclusivamente também por eles. A produção desta literatura histórica buscava ser cada vez mais seca e técnica, pois quanto mais inacessivel ao leitor comum ela fosse mais valorizada ela seria em seu meio (Ariès, 2013, p.281-4).

Foi neste contexto que surgiu a concepção moderna de fato bistórico, muito aliada às noções de explicaşão e continuidade ela passou a ser vista como fato monumental, piorando ainda mais o apotegma de irrefutabilidade. Segundo Ariès, da aproximação da história com as ciências exatas, em busca de legitimidade científica no Dezenove, resultou que objetividade e cientificidade passaram a figurar como regra para o estudo da história (Ariès, 2013, p.289).

Toda esta configuração engendrou, por fim, uma clivagem entre a bistória escola e a história faculdade, desembocando na equivocada compreensão de 
aulas de história como uma equação de sucessivos eventos políticos, o que foi péssimo para o Ensino (Ariès, 2013, p.289-92).

Por fim, o autor também refletiu sobre a resistência dos historiadores profissionais em investigar o sentido beurístico e epistemológico da História. Fundados numa compreensão tacanba e no desdém, os profissionais da história taxaram de palavrório inútil e sem empiria a discussão sobre a Filosofia da História, assinalou Ariès (Ariès, 2013, p.287). Tributário deste entendimento, os trabalhos de Filosofia da História que conhecemos não foram realizados por historiadores, mas por filósofos. Os poucos trabalhos devotados à mecânica do ofício histórico se ocuparam, assim, apenas de discutir tópicos técnicos da pesquisa: o uso do rol de Documentos, Arquivos, levantamento Bibliográfico, etc.

No Capitulo vii - História existencial - encontra-se a afirmação de que a renovação da História se deu a partir dos trabalhos de Marc Bloch e Lucien Febvre, os proeminentes historiadores dos Annales.

A contribuição de Bloch pode ser evidenciada, nos termos de Ariès, em suas duas grandes inovações, quais sejam, a História Regional e a Longa Duração. O estudo A sociedade feudal de Bloch (1990) foi revolucionário ao implantar a ideia mentalidade feudal ao rol de temas do trabalho histórico. Isto é, a inovação de Marc Bloch esteve na afirmação da não existência de um Feudalismo que atravessava todo o Ocidente, mas feudalismo(s) diferentes, organizados em torno de uma mentalidade feudal, que transpunha limites geográficos e políticos. Com isso, ele efetivava seu exercício metodológico de discutir e comparar distintas localizações tempo-espacial dos acontecimentos históricos, finalizou Ariès (2013, p.302-7).

Por sua vez, o trabalho de Lucien Febvre, na compreensão de Áries, é inseparável do de Marc Bloch. Assim, o livro Problema da incredulidade no século XVI: a religião de Rabelais, de Febvre (2009) é o maior exemplo da continuidade da investigação blochqueana sobre a Mentalidade.

Este ensaio, como vemos, foi profuso em ensinamentos sobre Teoria e Metodologia da História. Neste passo, a última lição ficou a cargo de uma advertência do mestre Ariès sobre a impossibilidade de se retornar ao passado. 
Para o historiador, a singularidade dos tempos vividos somente se dá ao historiador - sujeito do tempo presente - de forma indireta, isto é, pelas fontes (Ariès, 2013, p.310).

No Capitulo viii - História na civilização moderna - vimos uma descrição dos primeiros contatos de Ariès com a História, ainda na infância, e sua discussão sobre as duas concep̧ões de história com as quais mais conviveu no mundo de sua vida adulta: a História Política e a História Científica.

Segundo o historiador, a História Política estava fundada na ideia de repetição do fato histórico. Já a História Científica, de sua parte, à maneira da Sorbonne, era "austera, abstrata, seca, objetiva" e esforçava-se para tomar lugar como ciência, donde se explicava seu foco na objetividade (Ariès, 2013, p.321).

De modo a explicar a imbricação entre as duas, Ariès comentou um Programa de Conferências que submeteu a um ciclo de Estudos Sociais que foi rejeitado sob o argumento de "não se prestar a conclusões políticas suficientemente práticas e eficazes". No estudo, Ariès pretendia utilizar um método de análise das experiências concretas vividas para estudar as classes sociais. Ou seja, o "pecado" do historiador foi querer trabalhar com informantes na pesquisa, o que a fez ser sumariamente rejeitada, considerada ineficaz e subjetiva. Realidade que assinala bem a perspectiva tradicional e objetivista da época (Ariès, 2013, p.323).

Apontou também o autor que ao longo da História da História a disciplina deixou de ser considerada como um objeto de conbecimento desinteressado ou especulação orientada e passou a se vista como uma consciência existencial. Isto é, cresceu o entendimento de que História é a consciência de presença do sujeito no mundo, a partir de uma localização, que é espacial, social e temporalmente determinados (Ariès, 2013, p.324ss).

Por sua vez, a observação das multifacetadas realidades existentes promoveu que o historiador refletisse sobre a possibilidade de um ramo de pesquisa histórica efetivado a partir da História Individual e Coletiva. 


\section{Notas finais}

Embora o respaldo do magistério acadêmico lhe tenha demorado em demasia, Philippe Ariès é considerado um historiador que marcou a sua geração. Seus estudos sobre a origem e a força dos diversos hábitos econômicos, sociais, políticos, religiosos e literários - que ao se acumularem transformam as pessoas e o seu contexto foram significativos na construção do gênero de pesquisa histórica chamado História das Mentalidades, hoje em dia mais comumente nomeado, por variadas razões, como História Cultural. ${ }^{9}$

Para Roger Chartier (2013), a singularidade do pensamento de Ariès se explica por dois principais abalos epistêmicos: de um lado, pela imensa Literatura de testemunhos a que ele teve contato enquanto era avaliador da Editora Plon (i). De ouro lado, pela profunda influência sofrida do Movimento dos Annales, especialmente os trabalhos de Marc Bloch e Lucien Febure (ii).

Nestas condições, (i) a leitura das histórias pessoais abriu seus olhos para a complexa imbricação entre as existências individuais com a história coletiva. $\mathrm{O}$ que o moveu rumo à derrubada das fronteiras fixas entre o público e o privado, posicionamento que lhe rendeu um de seus mais célebres trabalhos A Criança e a Vida Familiar no Antigo Regime (Ariès, 1988), além da prestigiada coleção História da Vida Privada (2009). Por seu turno, (ii) Bloch e Febvre o incitaram à produção de uma história de recusa do político e do Estado, e uma história das diferenças, de modelação mais próxima à Etnografia, cuja primazia da Cultura e das Estruturas Mentais estava dada (Ariès, 1994, p.324ss e Chartier, 2013, p. 19ss).

Com efeito, o cenário até aqui esboçado esforçou-se por evidenciar que Philippe Ariès constitui mestre de primeira grandeza. Paradoxalmente, sua obra e ferramentas analíticas são precariamente difundidas entre pesquisadores em história do contexto contemporâneo. Realidade que se espraia também sobre o foco deste seu livro, a História da História.

\footnotetext{
${ }^{9}$ Conferir Roger Chartier (2013) e Ronaldo Vainfas (1996).
} 
Afinal, o leitor mais atento deve ter percebido que o mercado editorial tem estado muito produtivo nos últimos anos. Esta profusão livreira tem relação direta com a criação de Universidades e cursos de Ciências Humanas detidamente aqueles de formação docente -, ocorrida na última década.

Notadamente no campo da História, tem-se assistido a multiplicação de títulos, geralmente escritos por notórios docentes de universidades brasileiras, que, grosso modo, objetivam oferecer fundamentação epistêmica e conceitual aos jovens estudantes.

Dentre estes, há uma profusão sobre temas da divisão tradicional da História - Antiga, Média, Moderna e Contemporânea - com destaque para a História do Brasil - Colonial, Império e República. Por sua vez, a estes se somam os que debatem Historiografia e Escrita história, notadamente uma Introdução. ${ }^{10}$

No entanto, é recorrente, nestes últimos, o fato de se limitarem a retomar o século XIX, oscilando, neste recorte de tempo, apenas aos meandros da afirmação da História como campo científico específico; de modo que permanecem absolutamente obscurecidas as temporalidades e visões historiográficas mais remotas. Tem-se, então, a impressão de inexistência de História, enquanto campo de saber, e de debates sobre a produção, métodos e narrativa do conhecimento histórico antes do XIX. Temas estes, aqui vislumbrados, como vimos, de modo muito breve.

Neste contexto, as investigações de Philippe Ariès sobre as díspares concepções de história e de escrita histórica no transcorrer de tão complexa temporalidade e empiria preenchem, pois, um vazio enorme.

\footnotetext{
${ }^{10} \mathrm{Um}$ breve balanço sobre esta produção pode ser considerado a partir desta brevíssima bibliografia, majoritariamente nacional: BARROS, José D'Assunção. Teoria da História: a Escola dos Annales e a Nova História. Petrópolis: Editora Vozes, 2012. BARROS, José D’assunção. O campo da História: especialidades e abordagens. Petrópolis/RJ: Vozes, 2004; BASSANEZI, Carla (org.). Fontes históricas. São Paulo: Contexto, 2005; BURKE, Peter. A escola dos Annales (19291989): a Revolução Francesa da historiografia. São Paulo: Fundação Editora da UNESP, 1997; FREITAS, Mário Cezar de. Historiografia brasileira em perspectiva. São Paulo: Contexto, 2000; MONTENEGRO, Antonio. História, metodologia, memória. São Paulo: Contexto, 2010; PINSKY, Carla Bassanezi; LUCA, Tania Regina de (orgs.). O historiador e suas fontes. São Paulo: Contexto, 2009; REIS, José Carlos. Nowvelle Histoire e tempo histórico: a contribuição de Febvre, Bloch e Braudel. São Paulo: Ática, 1994.
} 
Reunidas, estas constatações fazem de O Tempo da História um livro seminal.

Não obstante suas inquestionáveis qualidades, a coletânea ressente-se em algumas partes de ser fastidiosa para os não especializados [capítulo v], é preciso confessar. Acontece que ele examina em profundidade autores e temas mui remotos e em desuso [História da França, Biografia de Joana D’arc, etc]. Assim, em algumas passagens é fundamental, de fato, se encorajar!

Outra dificuldade de adentramento na obra diz respeito à ausência de interligação interna nos ensaios. Escritos em anos diferentes, os textos são absolutamente independentes e sua sequenciação a posteriori deixou vácuos na argumentação.

Embora o longo e minucioso prefácio de Roger Chartier tenha perseguido a intenção de construir uma coerência interna, a imprecisão se aquilo que é sinalizado pelo leitor Chartier condiz com o que disse ou gostaria de ter dito o escritor Ariès resta constante. Noutras palavras, faltou uma conclusão do autor que retomasse seus principais argumentos, de modo a evitar indefinições.

A escrita e o léxico de Philippe Ariès merecem, ainda, uma ou duas palavras. Seus períodos longos e indiretos, muitas vezes têm de ser retomados se se busca a mais adequada compreensão. O mesmo sucede quando de suas muitas divagações e citações de exemplos, efetuadas em meio a uma longa afirmação. Percalços estes que, nem de longe se pense, em nada desmerecem a obra.

O historiador é, em tudo, um erudito. Sua escrita é elegante e caprichosa. Certamente vai exigir a companhia de dicionários bem como trará alguns novos vocábulos a muitos leitores. Por sua vez, a tradução cuidadosa de Roberto Leal Ferreira, ofertou muitas notas de expressões particulares do francês.

Deste modo, se desde os idos de sua primeira edição francesa, em 1959, Le Temps de l'Histoire já chamava atenção pelas terminologias 
historiográficas avant-garde que trazia à baila. $\mathrm{O}$ que fez enfurecer muitos acadêmicos. Em dias atuais, além de enriquecer o vocabulário, as chaves de leitura e os modos de empiria do historiador do séc. XXI, a obra, sem dúvida, ofertará importantes lições de História da História.

\section{Referências Bibliográficas:}

ARIÈS, Philippe; BÉJIN, André. Sexualités Occidentales - Contribution à l'histoire et à la sociologie de la sexualité; Communications, Revue Persée, n.35, 1982.

ARIÈS, Philippe. A criança e a vida familiar no Antigo Regime. Lisboa: Relógio d'Água, 1988.

ARIÈS, Philippe. Essais de Mémoire (1943-1983), Paris, Seuil, 1993.

ARIÈS, Philippe. Um historiador diletante. Rio de Janeiro: Bertrand Brasil, 1994.

ARIÈS, Philippe. O Tempo da História. Tradução de Roberto Leal Ferreira. São Paulo, Editora Unesp, 2015.

BLOC, Marc. A sociedade Feudal. Lisboa: Edições 70, 1990.

BOURDIEU, Pierre. O campo científico. In: Sociologia. Renato Ortiz (org.). São Paulo: Ática, 1983.

BRAUDEL, Fernand. La Méditerranée et le monde méditerranéen à l'époque de Philippe II. Paris, A. Colin, 1949.

BRAUDEL. Fernand. História e Ciências Sociais: A longa duração. Revista de História, USP. v.30, nº2, Abril-Junho, 1965.

BRAVO, Gutmaro Gómez. La historia social británica: memoria de una contribución colectiva. Revista de Historia y Comunicación Social. Universidad Complutense, Madri, n.8, 2003.

BURKE, Peter. A Revolução Francesa da historiografia: a Escola dos Annales 19291989. São Paulo: Editora Universidade Estadual Paulista, 1991;

CAMPOS, Raquel Discini de. PHILIPPE ARIÈS: A PAIXÃO PELA HISTÓRIA. Cadernos de História da Educação - v. 11, n. 1 - jan./jun., 2012.

CHARTIER, Roger. Introdução. In.: Philippe Ariès. O Tempo da História. Tradução de Roberto Leal Ferreira. São Paulo, Editora Unesp, 2015.

COUTAU-BÉGARIE, Hervé. Le phénomène "nouvelle histoire", stratégie et ideólogie des nouveaux historiens, Paris, 1983.

DUBY, Georges. A história continua. Rio de Janeiro, Zahar, 1993. 
DUBY, Georges. História da Vida Privada. São Paulo: Companhia das Letras, 2009.

DUBY, Georges. Mes ego-histoires, Paris, Gallimard, 2015.

ESTADO DE SÃO PAULO, O. 16.05.2014, Textos de Philippe Ariès revelam autor que fugiu das batalhas acadêmicas, de Rodrigo Petronio.

FEBVRE, Lucien. O problema da incredulidade no século XVI: a religião de Rabelais. São Paulo: Companhia das Letras, 2009.

GROS, Guillaume. Philippe Ariès, entre traditionalisme et mentalités. Itinéraire d'un précurseur, Vingtième siècle. Revue d'bistoire, n 90, avril-juin 2006.

GROS, Guillaume. Philippe Ariès (1914-1984) - Un traditionaliste non-conformiste: de l'Action française à l'École des Hautes Études en Sciences Sociales. Tese doutorado sob orientação de Serge Berstein, Villeneuve d'Ascq, Presses Universitaires du Septentrion, 2008.

GROS, Guillaume. Culture politique et vocation d'histoire chez Philippe Ariès. Cahier d'histoire immédiate, Toulouse, n 39, printemps, 2011.

GROS, Guillaume. Philippe Ariès e seus arquivos: da memória do historiador à do militante. Revista Tempo e Argumento, Florianópolis, v. 5, n. 9, 2013.

LE FIGARO, JORNAL. 22.05.1997, Philippe Ariès: un bistorien en reaction. Critique littéraire, de Emmanuel Le Roy Ladurie.

MÜLLER, Bertrand. Marc Bloch, Lucien Febure et les Annales d'histoire économique et sociale: correspondance, tome premier, 1928-1933.Paris: Fayard, 1994.

NEVES, Guilherme Pereira das. Chegará o tempo da história? Revista História da Historiografia. Ouro Preto, n.9, Agosto, 2012.

NORA, Pierre. Ensaios de ego história. Lisboa, Edições 70 Ltda., 1989.

NOVAIS, Fernando Antonio. Historiografia, exame de consciência dos historiadores. Economia e Sociedade, n. 4 (1), Campinas, 2016.

SILVA. Marcos. Philippe Ariès: um historiador marginal. Conferência. Univ. Federal de Sergipe. Sergipe. Mimeo, [Sd].

VAINFAS, Ronaldo. História da vida privada: dilemas, paradigmas, escalas. Anais do Museu Paulista. São Paulo. v.4 jan./dez., 1996. 